\author{
Wanda Klepacka \\ Ilona Pietucha \\ Wydział Inżynierii Produkcji \\ Politechnika Warszawska
}

\title{
Ustawa o niektórych formach wspierania działalności innowacyjnej - narzędziem aktywizacji gospodarczej
}

W dniu 29.07.2005 r. Sejm RP uchwalił Ustawę o niektórych formach wspierania działalności innowacyjnej (Dz.U. Nr 179, poz. 1484). Jej treść zmieniła niektóre zapisy ustaw: o podatku rolnym (z 15.11.1984 r.), o jednostkach badawczo-rozwojowych (z 25.07.1985 r.), o podatkach i opłatach lokalnych (z 12.01.1991 r.), o podatku dochodowym od osób fizycznych (z 26.07.1991 r.), o podatku dochodowym od osób prawnych (z 15.02.1992 r.), o Bankowym Funduszu Gwarancyjnym (z 14.12.1994 r.), o utworzeniu Polskiej Agencji Rozwoju Przedsiębiorczości (z 9.11.2000 r.), o finansowym wspieraniu inwestycji (z 20.03.2002 r.), o podatku leśnym (z 30.10.2002 r.), o podatku od towarów i usług (z 11.03.2004 r.) i o zasadach finansowania nauki (z 8.10.2004 r.). Ustawa o niektórych formach wspierania działalności innowacyjnej weszła w życie 20.10.2005 r.

Na stronie internetowej Ministerstwa Gospodarki można przeczytać: „Ustawa jest ukierunkowana na powstrzymanie nasilających się od szeregu już lat negatywnych zjawisk, takich jak: spadek udziału nakładów na działalność badawczo-rozwojową w PKB, niska innowacyjność przedsiębiorstw, brak zachęt dla przedsiębiorstw do ponoszenia zwiększonych wydatków na innowacje. Cel główny ustawy to wzrost konkurencyjności i innowacyjności gospodarki poprzez wzrost nakładów sektora prywatnego na badania i rozwój oraz poprawa efektywności gospodarowania środkami publicznymi przeznaczonymi na prace badawczo rozwojowe $(B+R)$.

Ten cel zostanie zrealizowany poprzez 4 cele cząstkowe, zdefiniowane jako:

- rozwój prywatnego sektora badawczo-rozwojowego,

- poprawa efektywności wdrażania polityki innowacyjnej na poziomie krajowym i regionalnym,

- wzrost efektywności wykorzystywania środków publicznych przeznaczonych na działalność innowacyjna,

- zwiększenie zainteresowania działalnością innowacyjną podmiotów sektora prywatnego wyrażone wzrostem nakładów przedsiębiorstw na działalność badawczo-rozwojową. ${ }^{1}$

Narzędziami realizacji powyższych celów będą:

- nowy instrument finansowy w postaci kredytu technologicznego,

- nadawanie przedsiębiorcom statusu centrów badawczo-rozwojowych,

- zmiany w prawie podatkowym,

- rozszerzenie zadań Polskiej Agencji Rozwoju Przedsiębiorczości”.2

\footnotetext{
${ }^{1}$ http://www.mgip.gov.pl

${ }^{2}$ Ibidem.
} 
Ustawa realizuje jedynie niektóre z tych celów. Już w przepisach ogólnych (rozdział pierwszy) ustawodawca zdefiniował następująco regulacje określone w niniejszym akcie prawnym:

„Art. 1.

Ustawa określa:

1) niektóre formy wspierania działalności innowacyjnej, w szczególności zasady i tryb udzielania kredytu technologicznego i umarzania części tego kredytu;

2) zasady nadawania statusu centrum badawczo-rozwojowego".3

Na podstawie treści przytoczonego artykułu można przypuszczać, że narzędzia przewidziane przez ustawodawcę nie są w stanie sprostać realizacji celów cząstkowych, w szczególności 2 i 3.

\section{Kredyt technologiczny}

W rozdziale drugim ustawy zostały określone zasady tworzenia, przyznawania i umarzania kredytu technologicznego. Ponadto ustawa lokuje Fundusz Kredytu Technologicznego w Banku Gospodarstwa Krajowego:

„Art. 3.

1. Kredyt technologiczny jest udzielany przez Bank Gospodarstwa Krajowego ze środków Funduszu Kredytu Technologicznego, o którym mowa w art. 9.

2. Kredyt technologiczny nie może być udzielany na realizację:

1) dużej inwestycji lub

2) inwestycji w sektorze hutnictwa żelaza i stali, włókien syntetycznych, górnictwa węgla i rybołówstwa oraz na działalność związaną z produkcją, przetwarzaniem i wprowadzaniem do obrotu produktów, o których mowa w Załączniku nr 1 do Traktatu ustanawiającego Wspólnotę Europejską". ${ }^{4}$ W punkcie czwartym art. 3 zastrzega się, że: „Kredytu technologicznego nie udziela się przedsiębiorcy będącemu w trudnej sytuacji ekonomicznej lub w okresie restrukturyzacji realizowanej z udziałem pomocy publicznej, chyba, że jest mikroprzedsiębiorcą lub małym przedsiębiorcą w rozumieniu rozporządzenia Komisji (WE) nr 70/ /2001/WE z dnia 12 stycznia 2001 r. w sprawie zastosowania art. 87 i 88 Traktatu WE w odniesieniu do pomocy państwa dla małych i średnich przedsiębiorstw (Dz.Urz. WE L $10 \mathrm{z}$ 13.01.2001), zmienionego rozporządzeniem nr 364/2004/WE z dnia 25 lutego $2004 \mathrm{r}$. (Dz.Urz. WE L 63 z 28.02.2004), zwanego dalej „,rozporządzeniem nr 70/2001”. 5

Z zapisów wcześniejszych omawianej ustawy wynika, że „przedsiębiorca w trudnej sytuacji ekonomicznej" to taki:

a) którego wielkość niepokrytej straty z lat ubiegłych łącznie z wynikiem finansowym roku bieżącego przewyższa 50\% wartości kapitału zakładowego i wielkość straty w ostatnim roku obrotowym przewyższa $25 \%$ wartości kapitału zakładowego - w przypadku spółki kapitałowej,

b) którego wielkość straty przewyższa 50\% wartości majątku spółki, stanowiącego mienie wniesione jako wkład lub nabyte przez spółkę i wielkość straty w ostatnim roku obrotowym przewyższa $25 \%$ wartości tego majątku - w przypadku spółki niebędącej spółką kapitałową,

c) który spełnia kryteria kwalifikujące do wszczęcia wobec niego postępowania upadłościowego. ${ }^{6}$

\footnotetext{
${ }^{3}$ Art. 1 Ustawy z dnia 29 lipca 2005 r. o niektórych formach wspierania działalności innowacyjnej, Dz.U. Nr 179, poz. 1484.

${ }^{4}$ Art. 3 p. 1 , ibidem.

${ }^{5}$ Art. 3 p. 4, ibidem.

${ }^{6}$ Art. 2 ust. 13, ibidem.
} 
Zapisy ustawy dotyczące kredytu technologicznego przewidują możliwość umorzenia do 50\% wartości kredytu, z zastrzeżeniem, że wysokość kapitału kredytu technologicznego nie może przekroczyć kwoty 2 mln euro, a całkowita kwota umorzenia nie może przekroczyć $1 \mathrm{mln}$ euro. Ustawa przewiduje również, że wysokość raty kredytu będzie wynosić $20 \%$ netto wartości wykazanej na fakturach sprzedaży innowacyjnych towarów lub usług powstałych w wyniku inwestycji.

\section{Centrum badawczo-rozwojowe}

Jak czytamy na stronie Ministerstwa Gospodarki: „celem nadawania przedsiębiorcom statusu Centrum Badawczo-Rozwojowego jest rozwój prywatnego sektora badawczo-rozwojowego oraz wzrost popytu na usługi B+R przez powiązanie statusu Centrum z zachętami podatkowymi". ${ }^{7} \mathrm{Nie}$ wydaje się słuszne twierdzenie, że samo stworzenie regulacji prawnych umożliwiających przedsiębiorcom utworzenie centrum badawczo-rozwojowego generuje wzrost popytu na usługi $\mathrm{B}+\mathrm{R}$, choćby z tej przyczyny, że wyniki prac funkcjonujących obecnie jednostek badawczo-rozwojowych (JBR) w małym stopniu wpływają na tworzenie popytu na usługi B+R. Można przypuszczać, że konieczne jest zatem przekształcenie organizacyjne JBR oraz transformacja skostniałej ich struktury, a nade wszystko zbliżenie tematyki badań realizowanych w tych jednostkach do realnych potrzeb przedsiębiorstw oraz podniesienie jakości tych badań. Niestety nie jest to możliwe bez nakładów finansowych, chociażby na nowoczesną aparaturę pomiarową. Wracając do omawianej ustawy: w art. 14 przewidziane zostały warunki utworzenia centrum badawczo-rozwojowego:

„Art. 12.

1. Przedsiębiorca niebędący jednostką badawczo-rozwojową może uzyskać status centrum badawczo-rozwojowego.

2. Status centrum badawczo-rozwojowego może uzyskać przedsiębiorca, o którym mowa w ust. 1:

1) którego przychody netto ze sprzedaży towarów, produktów i operacji finansowych za rok obrotowy poprzedzający rok złożenia wniosku, o którym mowa w ust. 6 , wyniosły co najmniej równowartość w złotych 800000 euro przeliczoną według średniego kursu ogłaszanego przez Narodowy Bank Polski na ostatni dzień roku obrotowego poprzedzającego rok złożenia wniosku;

2) którego przychody netto ze sprzedaży wytworzonych przez siebie wyników badań lub prac rozwojowych stanowią co najmniej 50\% przychodów określonych w pkt 1 ;

3) który nie zalega z zapłatą podatków, składek na ubezpieczenia społeczne i składek na ubezpieczenie zdrowotne". ${ }^{8}$

W dalszych zapisach ustawy przewiduje się, że przedsiębiorca, który uzyskał status centrum badawczo-rozwojowego, będzie zwolniony z podatku od nieruchomości (w tym od nieruchomości rolnych i leśnych) wykorzystywanych do prowadzenia badań i prac rozwojowych.

\section{Nowe zadania Polskiej Agencji Rozwoju Przedsiębiorczości}

Przepisy zawarte w omawianej ustawie poszerzają zakres zadań realizowanych przez Polską Agencję Rozwoju Przedsiębiorczości (PARP). Do zadań Agencji należy:

1. działanie na rzecz realizacji założeń polityki innowacyjnej państwa,

2. wspieranie i promocja przedsięwzięć, w tym programów, centralnych i regionalnych, w zakresie rozwoju innowacyjności,

3. przygotowywanie i realizacja własnych programów działań wspierających działalność innowacyjną,

\footnotetext{
${ }^{7}$ www.mpig.gov.pl

${ }^{8}$ Art. 12 Ustawy z dnia 29 lipca 2005 r. o niektórych formach wspierania działalności innowacyjnej, Dz.U. Nr 179, poz. 1484.
} 
4. wspomaganie organów administracji rządowej i samorządowej w zbieraniu i przetwarzaniu danych o potrzebach gospodarki narodowej w zakresie innowacyjności,

5. wspieranie działalności instytucji otoczenia przedsiębiorstw działających na rzecz wzrostu innowacyjności przedsiębiorstw i gospodarki, takich jak: jednostki badawczo-rozwojowe, centra badawczo-rozwojowe, centra transferu technologii, inkubatory przedsiębiorczości i parki technologiczne,

6. współpraca międzynarodowa w zakresie promocji i rozwoju innowacyjności. ${ }^{9}$

\section{Zmiany w prawie podatkowym}

Niniejsza ustawa wprowadza również zmiany w obowiązującym prawie podatkowym. Dotyczą one przepisów o podatku dochodowym od osób fizycznych (PIT) i od osób prawnych. Zgodnie z treścią ustawy:

- przedsiębiorca może odliczyć od podstawy opodatkowania cenę zakupu nowej technologii od jednostek naukowych polskich lub zagranicznych w wysokości nie większej niż 50\% w przypadku mikro, małych i średnich przedsiębiorstw oraz $30 \% \mathrm{w}$ przypadku pozostałych przedsiębiorstw,

- wydatki na prace rozwojowe, niezależnie od wyniku, jakim się zakończyły, można w myśl przepisów ustawy zaliczyć w koszty,

- ulega skróceniu okres amortyzacji zakończonych prac rozwojowych z 36 do 12 miesięcy,

- wprowadza się 22\% stawkę podatku VAT na usługi naukowo-badawcze.

Wymienione zapisy ustawy zmieniające obowiązujące prawo podatkowe, zdaniem autorów niniejszego artykułu, częściowo służą realizacji czwartego celu cząstkowego ustawy.

\section{Nowelizacja Ustawy o niektórych formach wspierania dzialalności innowacyjnej}

19.05.2006 r. weszła w życie nowelizacja ustawy o niektórych formach wspierania działalności innowacyjnej. Zawarte w niej przepisy dotyczące podatków weszły w życie z datą wsteczną, 1.01.2006 r. Oto najważniejsze zmiany, jakie wprowadza omawiana nowelizacja:

- firmy mogą skorzystać z ulgi podatkowej, jeśli zakupią nową technologię od prywatnych instytutów naukowo-badawczych,

- wprowadzono jeden limit odliczenia podatkowego 50\% ceny nowej technologii niezależnie od tego, czy z ulgi korzysta małe, średnie czy duże przedsiębiorstwo (poprzednio stawki były zróżnicowane i wynosiły odpowiednio 50\% i 30\%),

- wydłużono comiesięczny termin przekazywania środków pieniężnych na fundusz innowacyjności z ostatniego dnia każdego miesiąca na 15 dzień następnego miesiąca,

- definicja „przedsiębiorcy w trudnej sytuacji ekonomicznej” została odniesiona do regulacji Unii Europejskiej (dzięki czemu uniknięto konieczności ponownej nowelizacji ustawy w związku $\mathrm{z}$ dostosowywaniem do prawodawstwa UE).

\section{Podsumowanie}

Jak wspomniano we wstępie, omawiana ustawa miała zapewnić wzrost konkurencyjności i innowacyjności gospodarki poprzez wzrost nakładów sektora prywatnego na badania i rozwój oraz poprawić efektywność gospodarowania środkami publicznymi przeznaczonymi na $B+R$. Według autorów niniejszego artykułu, ustawa o niektórych formach wspierania działalności

\footnotetext{
${ }^{9}$ Art. 24, ust. 1 b) Ustawy z dnia 29 lipca 2005 r. o niektórych formach wspierania działalności innowacyjnej, Dz.U. Nr 179, poz. 1484.
} 
innowacyjnej nie jest w stanie sprostać stawianym jej celom, ponieważ dotyczy bardzo wąskiego spektrum działań o charakterze regulacyjnym w zakresie podnoszenia innowacyjności i konkurencyjności polskiej gospodarki. Rzeczywisty wymiar efektów pracy legislatorów pracujących nad tą ustawą będzie można obserwować i ocenić poprzez analizę takich wielkości, jak:

- liczba powstałych centrów badawczo-rozwojowych;

- wyniki działalności centrów badawczo-rozwojowych (ekonomiczno-finansowe, naukowe),

- liczba udzielonych kredytów technologicznych;

- wielkość umorzenia kredytu technologicznego (łączna wartość i wartość średnia w przeliczeniu na jednego beneficjenta);

- wielkość odliczeń podatkowych z tytułu zakupu nowej technologii (łączna wartość i wartość średnia w przeliczeniu na jednego beneficjenta);

- stopień wywiązywania się PARP z zadań statutowych.

Niewatpliwie ustawa o niektórych formach wspierania działalności innowacyjnej jest odzwierciedleniem niektórych potrzeb MŚP $\mathrm{i}$ transformacji sektora $\mathrm{B}+\mathrm{R}$, nie wystarczy ona jednak do realizacji celu głównego, jakim jest poprawa wskaźników innowacyjności naszego kraju.

Początkowo kredyt technologiczny nie cieszył się dużą popularnością wśród potencjalnych kredytobiorców. W pierwszym okresie składania wniosków (październik 2005 r.) złożono 30 wniosków, spośród których 18 zostało zaakceptowanych pod względem kryterium ,,nowej technologii”. Zawarto 12 umów kredytowych na łączną kwotę 18,3 mln zł. W kwietniu $2006 \mathrm{r}$. w trakcie procedury kredytowej było już 120 wniosków na łączną kwotę $350 \mathrm{mln}$ zł.

\section{Literatura}

1. Ustawa z dn. 29 lipca 2005 r. o niektórych formach wspierania działalności innowacyjnej, Dz.U. Nr 179, poz. 1484

2. Ustawa z dnia 12 maja 2006 r. o zmianie ustawy o niektórych formach wspierania działalności innowacyjnej oraz niektórych innych ustaw, Dz.U. Nr 107, poz. 723

3. http://www.mgip.gov.pl

\section{Act of 29 July 2005 on Certain Forms of Support for Innovative Activities as a Tool for Economic Stimulation}

Development of Knowledge-Based Economy (KBE) depends on numerous factors and the most important is the cultural and organizational/technological transformation of the economy. The key factor in creating KBE in Poland is the stimulation of corporate innovation. One of the actions aimed for enhancing innovation in Polish economy is the enactment of regulations that facilite the development of small and medium-sized businesses.

On July 29th, 2005, Polish Sejm passed the Act on Certain Forms of Support for Innovative Activities (Dz.U. Nr 179, poz. 1484). Its main goals are: first, to stimulate economic competitiveness and innovation by raising expenditures of private sector on research and development, and second, to increase the effectiveness of managing public resources allotted for research and development. The Act is designed to encourage entrepreneurs to coparticipate in stimulating innovation processes in Polish economy by taking part in funding and realization of scientific research. 